\title{
Hubungan antara Status Gizi dengan Gigi Berjejal pada Anak Usia 11 sampai 12 Tahun di SD Negeri 45 Manado
}

\author{
Ciwinan H. Richter, ${ }^{1}$ Pritartha S. Anindita, ${ }^{1}$ Shirley E. S. Kawengian ${ }^{2}$
}

\author{
${ }^{1}$ Program Studi Pendidikan Dokter Gigi Fakultas Kedokteran Universitas Sam Ratulangi, \\ Manado, Indonesia \\ ${ }^{2}$ Bagian Gizi Fakultas Kedokteran Universitas Sam Ratulangi, Manado, Indonesia \\ Email: ciwinan@gmail.com
}

\begin{abstract}
Nutrition has a very important role during growth and development. It is a collection of biochemical substances that generally come from food used for the process of producing energy, growth, development, and maintenance of the body function. Poor nutrition will have an impact on the growth and development of teeth and mouth such as the occurrence of dental malformations, easily injury of soft tissues, and obstructed development of facial bones and jaws. This study was aimed to determine the relationship between nutritional status and crowded teeth in children aged 11 to 12 years. This was a descriptive and analytical study with a cross sectional design. This study was conducted at Elementary School 45 in Manado using a total sampling method. There were 39 subjects that were analyzed by using BMI/A anthropometry. The chi-square obtained a p-value of 0.376 for the relationship between nutritional status based on $\mathrm{BMI} / \mathrm{A}$ and crowded teeth. In conclusion, there was no relationship between nutritional status based on BMI/A and crowded teeth in students of Elementary School 45 aged 11-12 years in Manado.
\end{abstract}

Keywords: nutritional status; crowded teeth; children

\begin{abstract}
Abstrak: Gizi memiliki peran yang sangat penting selama masa tumbuh kembang karena gizi merupakan kumpulan zat biokimia yang umumnya berasal dari makanan yang digunakan untuk proses menghasilkan energi, pertumbuhan, perkembangan, dan pemeliharaan tubuh. Gizi yang kurang baik akan berdampak pada pertumbuhan dan perkembangan gigi dan mulut seperti terjadi malformasi gigi, mudah terjadi cedera pada jaringan lunak, serta terhambatnya perkembangan tulang wajah dan rahang. Penelitian ini bertujuan untuk mengetahui hubungan antara status gizi dengan gigi berjejal pada anak usia 11 sampai 12 tahun. Jenis penelitian ialah analitik deskriptif dengan desain potong lintang. Penelitian ini dilaksanakan di Sekolah Dasar Negeri 45 Manado menggunakan total sampling dengan subjek penelitian berjumlah 39 orang, dianalisis menggunakan antropometriIMT/U. Hasil uji chi-square mendapatkan nilai $\mathrm{p}=0,376$ terhadap hubungan antara status gizi berdasarkan IMT/U dengan gigi berjejal. Simpulan penelitian ini ialah tidak terdapat hubungan bermakna antara status gizi berdasarkan IMT/U dengan gigi berjejal pada anak usia 11 sampai 12 tahun di SD Negeri 45 Manado.
\end{abstract}

Kata kunci: status gizi; gigi berjejal; anak

\section{PENDAHULUAN}

Gigi berjejal merupakan salah satu masalah kesehatan gigi dan mulut yang banyak dijumpai di Indonesia. Prevalensi gigi berjejal mencapai $80 \%$ dan menduduki urutan ketiga setelah karies dan penyakit periodontal. ${ }^{1}$ Hal ini cukup memrihatinkan, karena walaupun gigi berjejal bukan meru- pakan penyakit yang disebabkan oleh mikroorganisme baik bakteri maupun virus tetapi kelainan ini dapat memengaruhi estetika, sistem pengunyahan, dan fungsi bicara.

Gigi berjejal disebabkan oleh banyak faktor yang dapat dikelompokan menjadi faktor langsung dan tidak langsung. ${ }^{2,3}$ Faktor 
tidak langsung antara lain genetik, kongenital, dan keseimbangan kelenjar endokrin terganggu. Apabila kecukupan gizi untuk tumbuh kembang kurang, maka bukan hanya pertumbuhan dan perkembangan tubuh secara umum yang akan terganggu, namun juga tumbuh kembang gigi dan mulut. ${ }^{4,5}$ Hasil-hasil penelitian menunjukkan bahwa gizi yang kurang baik akan berdampak pada pertumbuhan dan perkembangan gigi dan mulut seperti malformasi gigi, mudah terjadi cedera jaringan lunak, terhambatnya perkembangan tulang wajah dan rahang, serta terjadinya susunan gigi berjejal. ${ }^{4}$ Selain itu defisiensi protein juga dapat memengaruhi dimensi panjang mandibula. Thomaz et $\mathrm{al}^{6}$ melakukan penelitian di Brazil tahun 2010 tentang hubungan malnutrisi dengan kasus gigi berjejal pada gigi permanen terhadap 2060 anak dengan landasan pengukuran status gizi secara antropometri berat badan per usia, dan melaporkan bahwa terdapat hubungan bermakna antara status gizi dengan kasus gigi berjejal. Purwaningsih et $\mathrm{al}^{7}$ menyatakan bahwa gigi berjejal dapat berdampak buruk pada sistem pengunyahan dan fungsi bicara pada anak. Menurut hasil riset kesehatan dasar (Riskesdas) tahun 2018, status gizi berkaitan dengan sosial ekonomi, tingkat pendidikan dan jenis pekerjaan. ${ }^{8}$ Status sosial ekonomi biasanya memiliki relevansi dengan kawasan pemukiman tertentu.

Berdasarkan pertimbangan tersebut penulis memilih Sekolah Dasar Negeri 45 Manado yang terletak di Kecamatan Tuminting Manado dengan rata-rata kondisi sosial ekonomi, pendidikan, dan jenis pekerjaan masyarakat menengah ke bawah. Anak usia 11 sampai 12 tahun dipilih sebagai subyek penelitian dengan pertimbangan bahwa pada usia tersebut gigi berjejal sudah lebih jelas untuk diamati dan anak di usia tersebut sudah lebih kooperatif untuk diperiksa. Pada penelitian ini dinilai gigi berjejal anterior dan posterior. Tujuan penelitian ini ialah untuk mengetahui hubungan gigi berjejal dengan status gizi pada anak usia 11 sampai 12 tahun di SD Negeri 45 Manado.

\section{METODE PENELITIAN}

Penelitian ini dilakukan terhadap siswa SD Negeri 45 Tuminting Manado. Jenis penelitian ialah analitik deskriptif dengan desain potong lintang. Populasi penelitian ini yaitu siswa-siswi usia 11 sampai 12 tahun di SD Negeri 45 berjumlah 39 orang. Sampel penelitian ini merupakan total sampling yaitu seluruh populasi yang memenuhi kriteria inklusi.

\section{HASILPENELITIAN}

Subyek penelitian terdiri dari 24 siswa berjenis kelamin laki-laki $(61,5 \%)$ dan 15 siswa berjenis kelamin perempuan $(38,5 \%)$. Siswa berusia 11 tahun sebanyak 25 orang $(64,2 \%)$ dan siswa yang berusia 12 tahun sebanyak 14 orang $(35,8 \%)$. Siswa dengan gigi berjejal sebanyak 33 orang $(84,6 \%)$, sedangkan yang tidak memiliki gigi berjejal sebanyak 6 orang $(15,4 \%)$.

Tabel 1 memperlihatkan pendidikan ayah yang terbanyak ialah SMA (48,7\%), sedangkan pendidikan ibu yang terbanyak ialah SMP $(51,4 \%)$.

Tabel 2 memperlihatkan pekerjaan ayah yang terbanyak yaitu nelayan $(66,6 \%)$ dan pekerjaan ibu yang terbanyak sebagai IRT $(94,8 \%)$.

Tabel 3 memperlihatkan bahwa kategori sangat kurus $(58,97 \%)$ yang terbanyak diikuti oleh kategori normal (33,33\%) sedangkan kategori kurus, gemuk, dan sangat gemuk berjumlah sama $(2,56 \%)$. Tabel 4 memperlihatkan bahwa siswa laki-laki dengan status gizi kategori kurus dan sangat kurus $(35,8 \%)$, lebih banyak daripada kategori normal atau lebih $(25,6 \%)$. Demikian pula siswa perempuan dengan status gizi kategori kurus dan sangat kurus $(25,6 \%)$ lebih banyak daripada kategori normal atau lebih $(12,8 \%)$.

Tabel 5 menunjukkan bahwa untuk usia 11 tahun kategori kurus dan sangat kurus $(33,3 \%)$ lebih banyak daripada kategori normal atau lebih $(30,7 \%)$, dan untuk usia 12 tahun kategori kurus dan sangat kurus $(28,2 \%)$ lebih banyak daripada kategori normal atau lebih $(7,69 \%)$.

Hasil uji Chi-Square mendapatkan nilai $\mathrm{p}=0,376$ yang menunjukkan tidak terdapat 
hubungan bermakna antara status gizi pada anak usia 11 sampai 12 tahun di SD berdasarkan IMT/U dengan gigi berjejal Negeri 45 Manado.

Tabel 1. Distribusi subjek penelitian berdasarkan pendidikan orang tua

\begin{tabular}{ccccc}
\hline $\begin{array}{c}\text { Pendidikan } \\
\text { Terakhir }\end{array}$ & \multicolumn{2}{c}{ Pendidikan ayah } & \multicolumn{2}{c}{ Pendidikan ibu } \\
& $\begin{array}{c}\text { Jumlah } \\
(\mathrm{n})\end{array}$ & $\begin{array}{c}\text { Persentase } \\
(\%)\end{array}$ & $\begin{array}{c}\text { Jumlah } \\
(\mathrm{n})\end{array}$ & $\begin{array}{c}\text { Persentase } \\
(\%)\end{array}$ \\
\hline S1 & 1 & 2,56 & 1 & 2,56 \\
SD & 1 & 2,56 & 1 & 2,64 \\
SMP & 10 & 25,6 & 20 & 51,4 \\
SMA & 19 & 48,7 & 13 & 33,2 \\
SMK & 8 & 20,58 & 4 & 10,2 \\
Total & 39 & 100 & 39 & 100 \\
\hline
\end{tabular}

Tabel 2. Distribusi subjek penelitian berdasarkan pekerjaan orang tua

\begin{tabular}{lcc}
\hline \multicolumn{1}{c}{ Pekerjaan } & $\begin{array}{c}\text { Jumlah } \\
(\mathbf{n})\end{array}$ & $\begin{array}{c}\text { Persentase } \\
(\boldsymbol{\%})\end{array}$ \\
\hline Ayah & & \\
$\quad$ Polisi/Tentara & 2 & 5,12 \\
Guru & 1 & 2,56 \\
Swasta & 6 & 15,4 \\
Nelayan & 26 & 66,6 \\
Gojek & 2 & 5,20 \\
Pembuat rakit & 1 & 2,56 \\
Tukang kayu & 1 & 2,56 \\
Total & 39 & 100 \\
Ibu & & \\
Guru & 1 & 2,60 \\
Pembuat kue & 1 & 2,60 \\
IRT & 37 & 94,8 \\
Total & 39 & 100 \\
\hline
\end{tabular}

Tabel 3. Distribusi subjek penelitian berdasarkan status gizi IMT/U

\begin{tabular}{lcc}
\hline \multicolumn{1}{c}{ Status gizi } & Jumlah (n) & $\begin{array}{c}\text { Persentase } \\
(\boldsymbol{\%})\end{array}$ \\
\hline Sangat kurus & 23 & 58,97 \\
Kurus & 1 & 2,56 \\
Normal & 13 & 33,33 \\
Gemuk & 1 & 2,56 \\
Sangat gemuk & 1 & 2,56 \\
Total & 39 & 100 \\
\hline
\end{tabular}

Tabel 4. Distribusi status gizi IMT/U berdasarkan jenis kelamin

\begin{tabular}{lcccccc}
\hline $\begin{array}{c}\text { Jenis } \\
\text { kelamin }\end{array}$ & \multicolumn{2}{c}{$\begin{array}{c}\text { Kurus dan } \\
\text { sangat kurus }\end{array}$} & \multicolumn{2}{c}{$\begin{array}{c}\text { Normal atau } \\
\text { lebih }\end{array}$} & \multicolumn{2}{c}{ Total } \\
& $\mathrm{n}$ & $\%$ & $\mathrm{n}$ & $\%$ & $\mathrm{n}$ & $\%$ \\
\hline Laki-laki & 14 & 35,8 & 10 & 25,6 & 24 & 61,4 \\
Perempuan & 10 & 25,6 & 5 & 12,8 & 15 & 38,6 \\
Total & 24 & 61,4 & 15 & 38,4 & 39 & 100 \\
\hline
\end{tabular}


Tabel 5. Distribusi subjek penelitian status gizi IMT/U berdasarkan usia

\begin{tabular}{lcccccc}
\hline $\begin{array}{c}\text { Usia } \\
\text { tahun) }\end{array}$ & \multicolumn{2}{c}{ Kurus } & \multicolumn{2}{c}{$\begin{array}{c}\text { Normal atau } \\
\text { lebih }\end{array}$} & \multicolumn{2}{c}{ Total } \\
& $\mathrm{n}$ & $\%$ & $\mathrm{n}$ & $\%$ & $\mathrm{n}$ & $\%$ \\
\hline 11 & 13 & 33,3 & 12 & 30,7 & 25 & 64,2 \\
12 & 11 & 28,2 & 3 & 7,69 & 14 & 35,8 \\
Total & 24 & 61,5 & 15 & 38,5 & 39 & 100 \\
\hline
\end{tabular}

\section{BAHASAN}

Subjek penelitian yang berada di SD Negeri 45 Manado Kecamatan Tuminting mempunyai latar belakang tingkat sosial ekonomi orang tua menengah kebawah sehingga diasumsikan bahwa tingkat pengetahuan orang tua terhadap kesehatan gigi dan mulut masih sangat kurang. ${ }^{9}$ 'Pekerjaan orang tua yang terbanyak ialah ayah sebagai nelayan $(66,6 \%)$ sedangkan ibu sebagai ibu rumah tangga $(94,8 \%)$. Dalam hal tingkat pendidikan orang tua, yang terbanyak ialah SMA untuk ayah $(48,7 \%)$ dan SMP untuk ibu $(51,4 \%)$.

Berbagai penelitian telah melaporkan kejadian gigi berjejal dan maloklusi pada anak baik dalam hal prevalensi, status gizi, maupun kebutuhan akan terapi ortodontik. Pada penelitian ini didapatkan prevalensi kasus gigi berjejal yang cukup tinggi di SD Negeri 45 Manado yaitu 33 subyek (84,6\%), lebih banyak daripada yang tidak memiliki gigi berjejal yaitu sebanyak enam subyek $(15,4 \%)$. Hasil penelitian ini mendapatkan persentase gigi berjejal yang jauh lebih tinggi dibandingkan penelitian Ahammed et $\mathrm{al}^{10} \mathrm{di}$ India yang melaporkan prevalensi maloklusi pada anak yatim usia 12-15 tahun yang berjumlah 165 sampel dengan kasus gigi berjejal sebanyak $38,8 \%$. Pada penelitian oleh Riyanti et al $^{11}$ dilakukan pencetakan pada gigi anak-anak Sekolah Dasar di Bandung. Analisis model gigi hasil pencetak pada 96 anak usia 9-12 tahun di SDN 504 Tikukur dan SDN 104 Langensari-Senanggalih mendapatkan 50 anak $(52,08 \%)$ dengan kondisi gigi berjejal dan 46 anak $(47,92 \%)$ dengan kondisi gigi tidak berjejal. Tingkat keparahan gigi berjejal pada penelitian ini berada pada tingkat rendah dan sedang, yaitu berturut-turut $68 \%$ dan $32 \%$. Hasil penelitian oleh Bittencourt et al ${ }^{12}$ terhadap 4776 anak-anak berusia 6-10 tahun di Brazilia melaporkan bahwa hanya $14,83 \%$ subyek yang mempunyai oklusi normal sedangkan $85,17 \%$ mendapatkan kelainan oklusi sebesar $57,24 \%$ dengan maloklusi kelas I, 21,73\% kelas II, dan 6,2\% kelas III. Kebutuhan ortodontik preventif didapatkan pada 72,34\% subyek dan ortodontik interseptif pada 60,86\% subyek. Lagana et $\mathrm{al}^{13}$ melakukan penelitian di Tirana, Albania, terhadap 2617 anak berusia 7-15 tahun, terdiri dari 1257 anak laki-laki dan 1360 anak perempuan, kesemuanya belum mendapatkan terapi ortodontik. Maloklusi kelas I, II dan III serta asimetri didapatkan pada $40,4 \%, 29,2 \%, 3,2 \%$, dan $27,1 \%$ subyek secara berurut. Kebutuhan terapi ortodontik (IOTN grade 4 dan 5) didapatkan pada 1077 subyek (41,2\%). Penelitian oleh Migale et al ${ }^{14}$ terhadap anak berusia 10-11 tahun di Italia selatan melaporkan bahwa dengan menggunakan IOTN-DHC (Index of Treatment Need (orthodontics) - dental health component) mendapatkan 51,6\% subyek yang tidak/ sedikit membutuhkan terapi ortodontik, $26,8 \%$ borderline, dan $21,6 \%$ membutuhkan terapi ortodontik.

Sekitar 98\% dari pertumbuhan wajah akan terhenti pada usia 15 tahun pada perempuan dan pada usia 17-18 tahun pada laki-laki. ${ }^{15}$ Susilowati ${ }^{16}$ melakukan penelitian mengenai prevalensi maloklusi gigi anterior pada siswa Sekolah Dasar (Penelitian pendahuluan di SD 6 Maccora Walihe, Sidrap) dengan menggunakan survei epidemiologik dan desain potong lintang pada 157 anak dengan kisaran usia 6-12 tahun. Prevalensi maloklusi gigi anterior untuk crowding $26,75 \%$, protrusi $9,55 \%$, dan diastema $6,37 \%$. Sebagai penyebab utama dari gigi crowding kemungkinan besar ialah 
adanya gigi persistensi sebesar $24,2 \%$ dari populasi total.

Anak yang berada dalam lingkaran ekonomi rendah mengonsumsi makanan keras setiap hari dan sangat sedikit mengonsumsi makanan lunak karena masalah kemampuan dan keterjangkauan. Berbeda halnya dengan anak yang berada dalam lingkaran ekonomi lebih tinggi mengonsumsi makanan lunak sehingga struktur kraniofasial dapat berkembang akibat berkurangnya penggunaan tekanan kekuatan pengunyahan yang kemudian mengurangi keterlibatan fungsi rahang. Kurangnya persediaan pangan, kemiskinan, sanitasi, kurangnya pengetahuan masyarakat tentang gizi, menu seimbang dan kesehatan dapat mengakibatkan terjadinya gizi kurang. Sebaliknya, kemajuan ekonomi pada lapisan masyarakat tertentu disertai dengan kurangnya pengetahuan tentang gizi, menu seimbang, dan kesehatan berakibat pada peralihan pola kehidupan masyarakat dari pola tradisional kepada modern yang banyak mengandung protein, gula, dan lemak tetapi kurang sehat. Hal ini mengakibatkan sebagian masyarakat mengalami kesulitan dalam penyesuaian diri berkaitan dengan pola makan yang tinggi kalori, serba cepat dan praktis, sehingga pola hidup sehat menjadi terabaikan. Pada penelitian ini didapatkan bahwa persentase status gizi kurus dan sangat kurus lebih tinggi daripada status gizi normal dan lebih pada kedua jenis kelamin. Pekerjaan orang tua yang terbanyak ialah ayah sebagai nelayan $(66,6 \%)$ sedangkan ibu sebagai ibu rumah tangga $(94,8 \%)$ dengan tingkat pendidikan orang tua yang terbanyak ialah SMA untuk ayah $(48,7 \%)$ dan SMP untuk ibu $(51,4 \%)$.

Selain itu, masyarakat di pedesaan cenderung memiliki sosial ekonomi yang rendah sehingga lebih memikirkan kebutuhan pokok dari pada masalah kesehatan dirinya termasuk kesehatan gigi dan mulut. Namum perlu ditekankan bahwa penyebab kurang gizi bukan dari masalah desa atau kotanya. ${ }^{17}$ Laporan hasil Riset Kesehatan Dasar (RIKESDAS) tahun 2008 menyatakan bahwa prevalensi masalah kesehatan gigi dan mulut di pedesaan lebih tinggi dibanding dengan di perkotaan karena di pedesaan menerima perawatan/pengobatan gigi lebih rendah daripada di perkotaan. ${ }^{18}$ Prevalensi kasus gigi berjejal cukup tinggi pada anak usia tumbuh kembang yang berada di pedesaan. Tingginya prevalensi gigi berjejal di daerah pedesaan dapat diakibatkan karena kurangnya pengetahuan kesehatan gigi dan mulut serta keterbatasan fasilitas kesehatan dan tenaga medis sehingga anak usia tumbuh kembang yang bertempat tinggal di pedesaan sulit mendapatkan pengetahuan serta pelayanan kesehatan gigi dan mulut. Hasil penelitian ini selaras dengan penelitian yang dilakukan Ausim dan Hamid $^{19}$ di Surabaya yang menyatakan prevalensi gigi berjejal pada anak di pedesaan lebih tinggi dibandingkan anak di kota. Tingginya prevalensi tersebut dikarenakan sulitnya mendapatkan informasi atau pengetahuan mengenai kesehatan dan kurangnya pengawasan orang tua terhadap kesehatan anak. Hasil penelitian ini juga sesuai dengan penelitian yang dilakukan Hoesin ${ }^{20}$ di Palembang tahun 2007 yang mengemukakan bahwa pengetahuan pada 188 anak usia sekolah dasar sedikit sekali bahkan 4,26\% anak-anak tidak memiliki pengetahuan tentang perawatan susunan gigi yang tumbuh tidak normal. Hal ini menunjukkan bahwa pengetahuan yang diberikan oleh orang tua ke anak-anak khususnya perihal susunan gigi di masa pertumbuhan gigi masih sangat kurang. Usia 11 sampai 12 tahun digunakan pada penelitian ini karena merupakan usia dimana periode gigi bercampur (mixed dentition). Selain itu, umumnya pada anak usia 11 sampai 12 tahun pembentukan akar kaninus permanen mandibula telah selesai. ${ }^{21}$ Penulis lebih memilih usia 11 sampai 12 tahun dengan asumsi semua gigi permanen pada rahang atas, rahang bawah, depan (anterior), dan belakang (posterior) telah erupsi dan dapat diindentifikasi berjejal atau tidak.

Hasil penelitian yang dilakukan oleh Thomaz dan Valenca ${ }^{22}$ di Brazil menunjukkan adanya hubungan antara berat badan terhadap umur dan peningkatan prevalensi gigi berjejal pada anak-anak usia 3 sampai 5 tahun. Menurut para peneliti, malnutrisi 
merupakan keadaan gizi yang kekurangan, kelebihan, atau ketidakseimbangan energi dan protein yang berpengaruh terhadap perkembangan hormon salah satunya ialah growth hormone $(\mathrm{GH})$ yaitu hormon pertumbuhan yang mempunyai peran dalam pertumbuhan dan perkembangan tulang, termasuk tulang rahang. Hasil penelitian tersebut juga didukung dengan penelitian yang dilakukan Weissman et $\mathrm{al}^{23}$ di Inggris yang menyatakan bahwa adanya efek malnutrisi terhadap pertumbuhan dan perkembangan tulang fasial serta perkembangan otot dan tulang. Kekurangan protein yang disebut defisiensi dapat bermanifestasi terhadap terganggunya pertumbuhan rahang sehingga menyebabkan gigi berjejal.

Jika dihubungkan dengan penelitianpenelitian yang telah dipaparkan, bahasan dari artikel ini lebih ditekankan atau konsisten yang berpengaruh dari segi sosial ekonomi dan pengetahuan. Anak-anak di pedesaan cenderung mengonsumsi makanan yang keras dan sangat jarang mengonsumsi makanan lunak seperti makanan cepat saji yang banyak dikonsumsi anak-anak di perkotaan. Konsumsi makanan cepat saji ini tentu saja berhubungan dengan status sosial ekonomi serta pengetahuan dari orangtua, mengingat harganya yang relatif mahal namun makanan yang siap saji diproses agar lebih praktis dan tidak memerlukan tekanan pengunyahan yang kuat. Hasil penelitian ini sesuai dengan penelitian oleh Setyaningsih ${ }^{24}$ di Yogyakarta yang mengemukakan bahwa pola makan di perkotaan cenderung lebih mengonsumsi jenis makanan lunak.

Hubungan antara status gizi dengan gigi berjejal yaitu gizi memengaruhi terjadinya kasus gigi berjejal. Gizi yaitu kumpulan zat biokimia yang umumnya berasal dari makanan yang digunakan untuk proses menghasilkan energi, pertumbuhan, perkembangan, dan pemeliharaan tubuh. ${ }^{25} \mathrm{Hahn}^{26}$ melakukan penelitian di Jerman tahun 2010 terhadap anak dengan rentang usia 12-17 tahun dan melaporkan bahwa terdapat kasus gigi berjejal dengan persentase $40 \%$ atau sejumlah 932 anak dari keseluruhan sampel 2329 anak yang menunjukkan jumlah kasus tersebut cukup banyak. Hahn menyatakan ketika tulang rahang mempunyai nutrisi cukup selama perkembangan maka tulang rahang terbentuk datar meluas dan 32 gigi dapat erupsi tanpa halangan, namun ketika terjadi gizi kurang selama masa perkembangan, lengkung tulang tidak terbentuk datar dan meluas sehingga gigi menjadi berjejal.

\section{SIMPULAN}

Tidak terdapat hubungan antara status gizi dengan gigi berjejal pada anak usia 11 sampai 12 tahun di SD Negeri 45 Manado.

\section{Konflik Kepentingan}

Penulis menyatakan tidak terdapat konflik kepentingan dalam penulisan artikel ini.

\section{DAFTAR PUSTAKA}

1. Herijulianti E, Tati Si, Sri A. Pendidikan Kesehatan Gigi. Jakarta: Penerbit Buku Kedokteran EGC, 2001; p. 35.

2. Bustan MM. Penyakit yang Tidak Menular. Jakarta: Rineka Cipta, 1997; p. 36.

3. Foster TD. Buku Ajar Ortodonti (3rd ed). Jakarta: EGC, 1999; p. 240-1.

4. Almatsier S. Prinsip Dasar Ilmu Gizi. Jakarta: Gramedia Pustaka Utama, 2002; p. 35.

5. Kustono J, Nasution FH, Haryanto AG. Buku Ajar Ortodonti Jilid I. Jakarta: Penerbit Buku Kedokteran EGC, 2017; p. 45.

6. Thomaz EBAF, Cangussu MCT, da Silva AAM, Assis AMO. Is malnutrition associated with crowding in permanent dentition. Int J Environ. 2010;7:3532.

7. Purwaningsih YRW, Ardhana W, Christnawati. Perawatan Maloklusi kelas III dengan Reverse overjet Menggunakan Alat Ortodontik Cekat Teknik Begg. Maj Ked Gi. 2013;20(1):112-8

8. Laporan Riset Kesehatan Dasar Tahun 2018. Jakarta: Badan Penelitian dan Pengembangan Kesehatan Departemen Kesehatan, Republik Indonesia, 2018; p. 483.

9. Setiawan HM, Sulistyowati E, Mifbakhuddin. Hubungan pendapatan perkapita, pengetahuan gizi ibu, dan aktifitas fisik dengan obesitas anak kelas 4 dan 5 di $\mathrm{SD} \mathrm{Hj}$. Isriati Baiturrahman Kota Semarang. J Kesehatan Masyarakat Indonesia (JKMI). 2005;2(1):7-12.

10. Ahammed ARY, Shetty V, Panda AK, Ginda $\mathrm{S}$, Pradhan $\mathrm{D}$, Husain $\mathrm{N}$, et al. 
Prevalence of malocclusion among 12 to 15 years age group orphan children using dental aesthetic index. J Contemp Dent Pract. 2013;14:111-3.

11. Riyanti E, Indriyanti R, Parimarti RS. Prevalensi maloklusi dan gigi berjejal berdasarkan jenis kelamin dan umur pada anak-anak sekolah dasar di Bandung. Available from: http://jurnal. unpad.ac.id $>$ pkm $>$ article

12. Bittencourt MAV, Machado AW. An overview of the prevalence of malocclusion in 6 to 10 -year-old children in Brazil. Dental Press J Orthod. 2010;15(6):113-22.

13. Lagana G, Masucci C, Fabi F, Bollero P, Cozza P. Prevalence of malocclusions, oral habits and orthodontiv treatment need in a 7-to 15-year-old school children population in Tirana. Prog Orthod. 2013;14:12.

14. Migale D, Barbato E, Bossù M, Ferro R, Ottolenghi L. Oral health and malocclusion in 10-to-11 years-old children in southern Italy. Eur J Paediatr Dent. 2009;10(1):13-8.

15. Capelli J Jr, Almeida RCC. Orthosurgical treatment of patients in the growth period: at what cost?. Dental Press J Orthod. 2012;17(1):159-77.

16. Susilowati. Prevalensi maloklusi gigi anterior pada siswa Sekolah Dasar (Penelitian pendahuluan di SD 6 Maccora Walihe, Sidrap). Makassar Dent J. 2016;5(3):97-101.

17. WHO. Physical status: the use and interpretation of anthropometry. Report of a WHO Expert Committee. Geneva: WHO, 2011; p. 35.

18. Riskesdas 2008. Jakarta: Badan Penelitian dan Pengembangan Kesehatan, Departemen Kesehatan, Republik Indonesia, 2008; p. 30.

19. Ausim S, Hamid S. Status of malocclusion in 912-years-old children: a survey among private and public school of Islamabad. $\mathbf{J}$ Med Res Health Educ. 2017;1:1.

20. Hoesin F. Indikator kebutuhan perawatan ortodonsia (IKPO) sebagai instrumen perencanaan pelayanan ortodonsia. J Dent Indones. 2007;14(3);236-42.

21. Liversidge H, Timing of Demirjian's tooth formation stages. Ann Hum Biol. 2006;33(4): 454-70.

22. Thomaz EBAF, Valenca AMG. Relationship between childhood underweihght and dental crowding in deciduous teething. J Pediatr. 2009;85:110-5.

23. Weissman S, Sadowsky PL, Jacobson A, Alvarez, JO, Caceda J. Craniofacial growth and development in nutritionally compromised Peruvian children. J Dent Res. 1993;72:366.

24. Setyaningsih P. Perbandingan derajat keparahan maloklusi dan kebutuhan perawatan ortodontik pada remaja etnik Jawa dan etnik Cina di Kodya Yogyakarta. Mutiara Medika. 2008;7(1):33-7.

25. Barasi ME. At A Glance: Ilmu Gizi. Jakarta: PT Gramedia Pustaka Utama, 2011; p. 89.

26. Hahn FE. Seputar Kesehatan Gigi dan Mulut. Jakarta: PT Gramedia Pustaka Utama, 2010; p. 40. 